\title{
Stjórnunaraðferðir og skipulag íslenskra fyrirtækja
}

\author{
Ingi Rúnar Eðvarðsson ${ }^{1}$
}

\begin{abstract}
Ágrip
Í pessari grein er kynnt rannsókn á skipulagi og stjórnunaraðferðum í íslenskum fyrirtækjum. Markmið hennar er í fyrsta lagi að skoða hvaða skipulagsform (skipurit) eru við lýði í íslenskum fyrirtækjum. Í öðru lagi er markmiðið að kanna hvaða stjórnunaraðferðir eru algengastar í íslenskum fyrirtækjum og í priðja lagi er markmiðið að athuga hvort pau hafi boðið út verkefni og tekið upp formlegt samstarf við önnur fyrirtæki. Niðurstöður benda til pess að staðsetning fyrirtækja á landinu og sú starfsgrein sem fyrirtæki starfa í hafi óveruleg áhrif á stjórnunaraðferðir eða skipulag peirra. Stærð fyrirtækja og menntun stjórnenda hafði hins vegar mjög mikil áhrif á marga pætti stjórnunar og skipulags, svo sem pegar stuðst var við sampykkt skipulag, liðsvinnu, samstarf fyrirtækja og útboð verkefna. Engin sjáanleg tengsl voru á milli stjórnunaraðferða og rekstrarárangurs. Helsta skýring pess er að mikill meirihluti fyrirtækja skilaði hagnaði árið 2003. Pörf er á frekari rannsóknum á stjórnunaraðferðum og skipulagi til að efla íslenskt atvinnulíf og tryggja varanlegan árangur fyrirtækja.
\end{abstract}

\begin{abstract}
This article introduces research into the organisation and management methods of Icelandic firms. Its chief objective is to examine the types of organisational structure used by Icelandic firms. A second aim is to discover which are the most widely used management styles in Icelandic business and a third objective is to investigate whether companies have outsourced particular activities and entered into formal cooperation with other enterprises. The results indicate that the geographical position of companies in Iceland and the sectors within which they operate do not have a significant impact on their management styles or organisation. Company size and managerial levels of education, however, strongly influenced numerous aspects of management and organisation, e.g. in the use of accepted organisational charts, teamwork, cooperation between companies and the outsourcing of particular tasks. There was no observable connection between management styles and operational success; the main reason for this being that a large majority of businesses returned a profit in 2003. Further research is required in the field of management methods and organisation in order to strengthen Icelandic industry and ensure the long-term success of companies.
\end{abstract}

JEL flokkun: L23; M1

Lykilhugtök: stjórnunaraðferðir, skipulag, islensk fyrirtæki; management, organization, Icelandic firms

\footnotetext{
${ }^{1}$ Höfundur er prófessor í stjórnun við Viðskipta- og raunvísindadeild Háskólans á Akureyri. Rannsóknin var fjármögnuð með styrk úr Rannsóknarsjóði Háskólans á Akureyri. Enn fremur var hún gerð möguleg með samningi milli Rannsóknarstofnunar Háskólans á Akureyri og Viðskipta- og raunvísindadeildar HA um rannsóknarvinnu. Helgi Gestsson og Ólafur Jakobsson lektorar unnu einnig að rannsókninni. Höfundur vill pakka Guðmundi Kristjáni Óskarssyni og tveimur nafnlausum ritrýnum gagnlegar ábendingar við vinnslu greinarinnar.
} 


\section{Inngangur}

Í pessari grein er kynnt rannsókn á skipulagi og stjórnunaraðferðum í íslenskum fyrirtækjum. Markmið hennar er í fyrsta lagi að kanna hvaða skipulagsform (skipurit) eru við lýði í íslenskum fyrirtækjum. Í öðru lagi er markmiðið að kanna hvaða stjórnunaraðferðir eru algengastar í íslenskum fyrirtækjum á sviði gæðastjórnunar, stefnumótunar, almennrar stjórnunar, pekkingarstjórnunar o.fl. Til að framfylgja markmiðum rannsóknarinnar eru eftirtaldar rannsóknarspurningar settar fram:

- $\quad$ Er munur á stjórnunaraðferðum og skipulagi milli fyrirtækja á landsbyggðinni, Akureyri og höfuðborgarsvæðinu?

- $\quad$ Er munur á stjórnunaraðferðum og skipulagi eftir starfsgreinum og stærð fyrirtækja?

- $\quad$ Er munur á stjórnunaraðferðum háskólamenntaðra stjórnenda og annarra stjórnenda?

- $\quad$ Er rekstrarárangur mismunandi eftir pví hvaða stjórnunaraðferðir fyrirtækin beita?

Stjórnunaraðferðir eru mikilvægar fyrir rekstur og afkomu fyrirtækja. Pannig hafa rannsóknir og reynslan leitt í ljós að stjórnun hefur áhrif á starfsánægju, frammistöðu og framleiðni starfsfólks, liðsvinnu, starfsmannaveltu og rekstrarárangur fyrirtækja (Griffin, 2002; Buchanan og Huzcynski, 2004; Kreitner, 2004; Mullins, 2005). Gögn og upplýsingar um stjórnun á Íslandi eru hins vegar tiltölulega takmarkaðar pó svo að pær aukist ár frá ári. Fátt er t.d. vitað um menntun íslenskra stjórnenda og stjórnunaraðferðir peirra. Ekki liggur fyrir með óyggjandi hætti hvort peir hafi tileinkað sér gæðastjórnun, árangursstjórnun, markmiðastjórnun, hagnýt viðmið, pekkingarstjórnun og samhæft árangursmat. Enn fremur er óljóst hvort stjórnunaraðferðir eru ólíkar eftir starfsgreinum og pannig má áfram telja. Hér að neðan er gerð grein fyrir helstu rannsóknum sem gerðar hafa verið í íslenskum fyrirtækjum um stjórnun og skipulag. Almennum, kenningarlegum rannsóknum, par sem ekki er hugað að fyrrgreindum páttum í fyrirtækjum, er sleppt.

Árelía Eydís Guðmundsdóttir (2002) hefur rannsakað tengsl á vinnumarkaði og samspil stjórnunarhátta í stofnunum og fyrirtækjum við samskipti aðila vinnumarkaðarins og ytra efnahagsumhverfi á árunum 1987-1995 á Íslandi. Hún ræddi við 41 stjórnanda í stærstu fyrirtækjum á Íslandi, auk pess sem hún studdist við vinnustaðagreiningu Gallups og önnur fyrirliggjandi gögn. Niðurstöður hennar leiða í ljós að ytri breytingar, svo sem efnahagskreppa, mikil óvissa og alpjóðavæðing, höfðu mikil áhrif á íslenska stjórnendur. Langtímastefnumótun, leiðtogahæfni og áætlanagerð urðu mun mikilvægari en áður og pað jók mjög pýðingu fagstjórnenda. Sami höfundur (2005) kannaði einnig áhrif viðhorfa 20 millistjórnenda í einu 200 manna hátæknifyrirtæki á árangur peirra í starfi. Árelía Eydís leggur vonarkenningu til grundvallar og kemst að pví að vongóðir stjórnendur séu líklegri til að ná meiri árangri við markmiðasetningu verkefna starfsmanna sinna en peir sem eru vonlitlir. Sama rannsókn og kenningarammi var notaður til að kanna samræmingu á milli vinnu og einkalífs hjá millistjórnendum. Niðurstöður eru pær að 
millistjórnendum sem hafa mikinn viljastyrk, eru útsjónarsamir og vongóðir gengur betur en öðrum að samræma vinnu og einkalíf (Inga Hanna Guðmundsdóttir og Árelía Guðmundsdóttir, 2005).

Harpa Björg Guðfinnsdóttir og Inga Jóna Jónsdóttir (2005) hafa fjallað um próun stjórnendahæfi í litlum og meðalstórum fyrirtækjum. Pær byggja niðurstöður sínar á rannsókn Hörpu Bjargar, en hún tók viðtöl við 10 stjórnendur í fyrirtækjum með 2-100 starfsmenn. Helstu niðurstöður eru pær að stór hluti af starfi viðmælendanna fer í að sinna starfsmanna- og sölumálum. Viðmælendur töldu einnig að félagsleg hæfni skipti mestu í starfi sínu. Við próun hæfni er páttur óformlegra leiða mikill og athygli vekur að frumkvöðlar sækja ekki formlegar námsleiðir.

Ása Guðbjörg Ásgeirsdóttir (2004) hefur rannsakað áhrif stjórnunarstíls og trú stjórnenda á eigin stjórnunarfærni á viðhorf undirmanna til starfs síns og sálfélagslegs vinnuumhverfis. Hún lagði spurningalista fyrir á níu vinnustöðum (fimm pjónustufyrirtækjum og fjórum stofnunum). Alls svöruðu 472 einstaklingar, par af 76 yfirmenn og 396 undirmenn peirra. Heildarsvörum var 69\%. Ása Guðbjörg leitaðist við að sýna fram á að undirmenn umbreytingarstjórnenda (e. transformational leadership) séu jákvæðari gagnvart starfi sínu og vinnuumhverfi en undirmenn stjórnenda sem sýna lítið af einkennum umbreytingarstjórnunarstíls. Niðurstöður hennar staðfesta pað. Undirmenn umbreytingastjórnenda voru ánægðari í starfi og fengu meiri hvatningu og stuðning frá yfirmanni sínum. Loks töldu peir að betur væri hugað аð mannauði og аð par ríkti menning og starfsandi sem hvetti fólk til nýbreytni. Rannsóknin studdi hins vegar ekki pá tilgátu að undirmenn aðgerðastjórnenda (e. transactional leadership) væru neikvæðari til starfs síns og sálfélagslegs vinnuumhverfis, að pví undanskildu að peir upplifðu meira andlegt álag í starfi en undirmenn umbreytingastjórnenda. Af öðrum niðurstöðum má nefna að trú á stjórnunarfærni hafði lítið forspárgildi um viðhorf undirmanna og að yfirmenn mátu sig að jafnaði með meiri umbreytingarstjórnunarstíl en undirmenn peirra gerðu. Pá töldu undirmenn að kvenkyns stjórnendur sýndu fleiri einkenni umbreytingarstjórnunarstíls en karlkyns stjórnendur.

Arney Einarsdóttir (2004) pýddi, staðlaði og prófaði réttmæti og áreiðanleika mælitækis og líkans evrópsku starfsánægjuvísitölunnar í meistararannsókn sinni. Auk pess nýtir hún niðurstöðurnar til að greina vægi helstu áhrifavalda starfsánægju hér á landi í norrænum samanburði. Arney lagði mælitækið fyrir í 12 opinberum fyrirtækjum og einkafyrirtækjum og endanlegur fjöldi pátttakenda var 346 talsins (65\% svarhlutfall). Rannsókn Arneyjar leiddi í ljós að mælitækið var réttmætt og áreiðanlegt til mælinga á starfsánægju, hollustu og tryggð, pó svo að hún legði til vissar endurbætur á pví til að ná enn frekari árangri. Helstu áhrifavaldar starfsánægju á Íslandi eru starf og starfsskilyrði, í öðru lagi ímynd og í priðja lagi starfspróun. Pegar Ísland er borið saman við önnur Norðurlönd vekur athygli að ímynd hefur meiri áhrif á starfsánægju í Finnlandi og á Íslandi en annars staðar og að samstarf hefur meiri áhrif á starfsánægju Svía. Danir reyndust ánægðastir í starfi en Svíar óánægðastir en Íslendingar virtust tryggastir og Danir og Íslendingar jafnframt hollastir. Раð vekur einnig athygli að áhrif páttarins stjórnun á starfsánægju er hverfandi hér á landi en sú var ekki raunin annars staðar á Norðurlöndum. Samsvörun milli landanna má hins vegar merkja á páttunum starf og starfsskilyrði og starfspróun. Loks má geta pess að rannsókn Arneyjar leiddi í ljós að konur eru 
ánægðari, hollari og tryggari starfskraftur en karlar og að fólk í skrifstofu- og pjónustustörfum er mun ánægðara í starfi en fólk í líkamlegri vinnu.

Greinarhöfundur hefur rannsakað útbreiðslu og árangur pekkingarstjórnunar í íslenskum fyrirtækjum (Ingi Rúnar Eðvarðsson, 2004; 2005). Par kemur fram að tiltölulega fá fyrirtæki hafa tekið upp aðferðir pekkingarstjórnunar, fá fyrirtæki hafa mótað stefnu um miðlun og nýtingu pekkingar og fyrirtækin hafa ekki fjárfest í hápróuðum pekkingarstjórnunarkerfum. Árangur pekkingarstjórnunar virðist vera mikill hjá peim fyrirtækjum sem hafa innleitt hana.

Af framansögðu má ráða að margar rannsóknir hafa verið gerðar á liðnum árum hér á landi um stjórnunaraðferðir, einkanlega í stærri fyrirtækjum. Heildstæða vitneskju um stjórnunaraðferðir í íslenskum fyrirtækjum skortir pó enn. Рað á einkanlega við um stöðu mála í minni og miðlungsstjórum fyrirtækjum. Af pessum sökum var ákveðið að ráðast í pá könnun sem kynnt er í pessari grein. Spurningum um mannauðsstjórnun var sleppt vegna pess að Cranet-rannsókn var í gangi um svipað leyti. Markmið Cranet-samstarfsins er að gera alpjóðlegar rannsóknir á mannauðsstjórnun og fylgjast með próun aðferða í mannauðsstjórnun í sögulegu ljósi. Spurningalisti var sendur til 246 fyrirtækja með fleiri en 70 starfsmenn árið 2003 en svör bárust frá 114 fyrirtækjum (46\%). Rannsóknin leiddi í ljós margháttaðar upplýsingar um mannauðsstjórnun í íslenskum fyrirtækjum sem ekki er tök á að rekja hér (Ásta Björnsdóttir, Finnur Oddsson, Hafsteinn Bragason, Inga Jóna Jónsdóttir og Tómas Bjarnason, 2004).

Í öðrum kafla eru rannsóknaraðferðir kynntar. Gerð er grein fyrir fyrirtækjum og stjórnendum í priðja kafla og skipulagi fyrirtækja í peim fjórða. Fjallað er um stjórnunaraðferðir í fimmta kafla og í sjötta kafla er samstarfi fyrirtækja og útboði verkefna lýst. Rekstrarárangri fyrirtækjanna í könnuninni er lýst í sjöunda kafla og helstu niðurstöður eru kynntar í lok greinarinnar.

\section{Rannsóknaraðferðir}

Sú rannsóknaraðferð sem best hentar markmiðum rannsóknarinnar er lýsandi rannsóknaraðferð (e. descriptive research). Slík aðferð miðast við að finna tíðni, hlutföll og tengsl breyta og að staðfesta eða hafna tilgátum. Tvær algengustu gerðir kannana eru spurningalistakannanir og viðtalskannanir (oftast í gegnum síma). Helstu kostir viðtalskannana er að tiltölulega auðvelt er að ná til fólks, og pað tryggir mikla svörun; aðferðin er skjótvirk; mögulegt er að koma í veg fyrir að spurningar séu misskildar og auðvelt er að fylgjast með gangi könnunarinnar. Kostir spurningalistakannana eru hins vegar að pær eru tiltölulega einföld leið til gagnaöflunar; ekki parf að ná til fólks á tilteknum tíma; engar skekkjur verða vegna áhrifa spyrla og svarendur hafa betra næði til að svara. Helsti ókostur peirra er lágt svarhlutfall (Churchill, 2002).

Spurningalistakönnun var valin í rannsókninni. Helsta ástæðan var að pannig yrði auðveldara að ná til stjórnenda en að taka símaviðtal við pá. Einnig hafði pað áhrif á val rannsóknaraðferðar að ný aðferð við gagnaöflun, p.e. netkannanir, var að ryðja sér til rúms. Rannsakendur vildu kanna hina nýju aðferð, enda býður hún upp á ódýra og einfalda leið til að afla gagna. Slíkar aðferðir eru einnig hraðvirkar auk pess sem pær fela í sér kosti spurningalistakannana. Helstu ókostir slíkra aðferða eru 
að úrtakslistar eru ekki aðgengilegir og pví er erfitt að velja fyrirtæki, pær krefjast aðgangs að neti og tæknileg vandamál geta komið upp á við framkvæmd könnunarinnar (Malhrota og Birks, 2003).

Könnunin hófst 18. maí 2004 og henni lauk 18. júní sama ár. Rannsóknarstofnun Háskólans á Akureyri sá um framkvæmd hennar. Sendur var spurningalisti til forstöðumanna fyrirtækja og stofnana eða staðgengla peirra sem viðhengi í tölvupósti. Outcome-forritið var notað til að halda utan um gögnin og taka saman frumniðurstöður en gögnin voru unnin frekar í SPSS-forriti. Ítrekun um pátttöku og spurningalisti var sendur prisvar sinnum til fólksins í úrtakinu til að auka svörun. Ekki var heitið neinum verðlaunum fyrir pátttöku.

Sú ákvörðun að senda spurningalista með tölvupósti getur falið í sér hættu á skekkju, svo sem að ungir, vel menntaðir stjórnendur í stærri fyrirtækjum svari frekar en aðrir stjórnendur. Svo reyndist ekki vera hvað stærð fyrirtækja varðar, par sem $84 \%$ stjórnenda í könnuninni stýrðu fyrirtækjum með færri en 20 starfsmönnum. A peim stjórnendum sem svöruðu höfðu 57\% lokið háskólanámi og meðalaldur peirra var 45 ár. Par sem upplýsingar liggja ekki fyrir um menntun og aldur íslenskra stjórnenda er erfitt að meta svörun út frá peim forsendum.

Úrtakið var tilviljanaúrtak valið af Hagstofu Íslands úr fyrirtækjum og stofnunum með fleiri en fimm starfsmenn. Úrtakið var lagskipt pannig að pað endurspeglaði staðsetningu fyrirtækja og starfsgreinar í réttum hlutföllum. Upphaflegt úrtak var 1280 fyrirtæki en endanlegt úrtak var 905 fyrirtæki en pað voru fyrirtæki sem höfðu netföng sem aðgengileg voru á heimasíðum eða í símaskrá. Pau skiptust jafnt milli höfuðborgarsvæðisins og annarra svæða (sjá nánar í næsta hluta greinarinnar).

Svör bárust frá 265 fyrirtækjum. Рað pýðir að svörun var 29,3\%. Takmörkuð svörun er velpekkt vandamál í spurningalistakönnunum. Aaker, Kumar og Kay rita t.d. (2001, bls. 226): „Á pví leikur enginn vafi að vandinn við lágt svarhlutfall einkennir spurningalistakannanir. Ef maður sendir einfaldlega spurningalista til venjulegs slembiúrtaks án viðeigandi áminninga, er líklegt að svörun verði innan við 20\%." Vandinn er oftar meiri í fyrirtækjakönnunum par sem tímaskortur og álag dregur úr svörun. Netkannanir juku svarhlutfall í fyrstu upp í 50-60\% en pað hefur lækkað niður í 25-30\% pegar nýjungabragurinn hefur horfið með aukinni notkun slíkra kannana (Burns og Bush, 2003).

Lágt svarhlutfall skapar vandkvæði við að túlka réttmæti rannsóknar. Er dreifing peirra sem ekki svöruðu eins og peirra sem svöruðu? Eins og fram kemur hér að aftan hafa pátttakendur í könnuninni eftirtalin sérkenni í samanburði við tölur frá Hagstofu Íslands um íslensk fyrirtæki almennt: Peir stýra fyrirtækjum með fleiri en 20 starfsmenn í meira mæli en almennt gerist (frávik 26 prósentustig); fleiri koma úr einkahlutafélögum en öðrum rekstrarformum (frávik 35,5 prósentustig), hlutfallslega fleiri eru búsettir á landsbyggðinni en almennt (frávik 5 prósentustig) og tiltölulega fleiri stýra fyrirtækjum í frumvinnslu og iðnaði en meðaltal segir til um (frávik 20,8 prósentustig). Niðurstöður verður að túlka með pað í huga.

Spurningalistinn innihélt 42 spurningar. Hann var að mestu smíð peirra sem stóðu að rannsókninni en stuðst var við aðra spurningalista um stjórnunaraðferðir (líkan Herseys og Blanchards, 1988), pekkingarstjórnun (sjá KPMG Consulting, 2000; Lim og Ahed, 2000) og árangursmælingar (sjá Nilsson og Kald, 2002). Spurningalistinn var forprófaður í tveimur fyrirtækjum og lagfærður lítillega í kjölfar 
pess. Spurningalistanum var skipt upp í bakgrunnsupplýsingar, skipulag og stjórnun, gæðastjórnun, pekkingarstjórnun og stefnumótun. Fjöldi svarmöguleika í hverri spurningu var frá einum (t.d. að skrá aldur sinn), premur (já/nei/veit ekki) upp í 17 svarmöguleika (t.d. hvaða upplýsingatæknikerfi eru í notkun í fyrirtækinu). Í nokkrum spurningum var heimilt að merkja við fleiri en eitt svar. Í flestum spurningunum var stuðst við nafna- eða röðunarskala sem aðeins heimila að reikna út fjölda, tíðni og að nota krosstöflur. Í spurningum um aldur og starfsaldur var stuðst við millibils- og hlutfallslega skala par sem flóknari tölfræði er möguleg. Við tölfræðilega úrvinnslu var algengast að reikna út fjölda og tíðni en krosstöflur voru oftast gerðar um tengsl stjórnunaraðferða og skipulags við stærð, staðsetningu og pá starfsgrein sem viðkomandi fyrirtæki starfar í, auk menntunar stjórnenda. P-gildi og kí-kvaðrat var jafnframt reiknað út. Til að skera úr um marktækni milli hópa (t.d. fyrirtæki á höfuðborgarsvæðinu og landsbyggðinni) var stuðst við tveggja hlutfalla próf. $^{2}$

Hér verður aðeins gerð grein fyrir peim hluta spurningalistans sem fjallar um skipulag og stjórnunaraðferðir.

\section{Fyrirtæki og stjórnendur}

Eins og fyrr segir bárust svör frá 265 fyrirtækjum. Um helmingur peirra (48,8\%) er staðsettur á höfuðborgarsvæðinu, 20,4\% eru á Akureyri og í nágrenni og önnur fyrirtæki dreifðust um landið (sjá töflu 1). Рað endurspeglar úrtakið vel sem var valið með landfræðilega dreifingu í huga, p.e. að um helmingur væri staðsettur á höfuðborgarsvæðinu og að 25\% væru á Eyjafjarðarsvæðinu pannig að mögulegt væri að greina fyrirtæki par sérstaklega. Helsta skekkjan í könnuninni er að hlutfallslega fleiri fyrirtæki á landsbyggðinni svara henni en fyrirtæki annars staðar á landinu.

Tafla 1. $\quad$ Landfræðileg dreifing fyrirtækja.

\begin{tabular}{lcc}
\hline & Úrtak & Svörun \\
\hline Höfuðborgarsvæði & $50,7 \%$ & $48,8 \%$ \\
Akureyri og nágrenni & $23,9 \%$ & $20,4 \%$ \\
Landsbyggð & $25,4 \%$ & $30,8 \%$ \\
\hline & $100,0 \%$ & $100,0 \%$ \\
\hline
\end{tabular}

Algengast var að fyrirtækin sem tóku pátt í könnuninni hefðu 11-20 starfsmenn á launaskrá árið 2003. ${ }^{3}$ Um 61\% fyrirtækjanna hafði 20 starfsmenn eða færri. Eins og áður hefur komið fram eru fyrirtækin í könnuninni nokkru stærri en skrá yfir stærð íslenskra fyrirtækja hjá Hagstofu Íslands gefur til kynna (Hagstofa Íslands, 2005a). Um helmingur fyrirtækjanna í pessari könnun hafði 1-5 háskólamenntaða starfsmenn árið 2003 en 22,9\% höfðu engan háskólamenntaðan starfsmann.

2 Formúlan er: $z=\frac{p_{1}-p_{2}}{\sqrt{\frac{p_{1}\left(100-p_{1}\right)}{n_{1}}+\frac{p_{2}\left(100-p_{2}\right)}{n_{2}}}}$

${ }^{3}$ Svarmöguleikar voru flokkaðir fyrir fram í spurningalista, p.e. 0-5, 6-10 o.s.frv. 
Algengast var að velta fyrirtækjanna árið 2003 væri á bilinu 101-400 milljónir (svarmöguleikar voru flokkaðir fyrir fram í spurningalista); $27 \%$ fyrirtækjanna höfðu veltu á bilinu 26-100 milljónir króna, 36\% fyrirtækjanna höfðu veltu á bilinu 101-400 milljónir og 21\% hafði veltu sem var yfir 700 milljónir.

Af peim stjórnendum sem svöruðu könnuninni höfðu 57\% lokið háskólanámi, 37\% höfðu framhaldsskóla- og iðnmenntun og 6\% svarenda höfðu eingöngu lokið grunnskólanámi. Karlstjórnendur voru 83\% svarenda og 17\% konur. Meðalaldur svarenda var 44,6 ár. Meðalstarfsaldur í núverandi fyrirtæki var 9,6 ár og 14,2 ár alls í greininni.

Algengasta rekstrarform fyrirtækja í könnuninni voru einkahlutafélög (ehf.), 59,3\% fyrirtækjanna voru skráð með peim hætti. Pví næst komu almenningshlutafélög eða 19,8\% fyrirtækja í könnuninni, 6,8\% svarfyrirtækja voru fyrirtæki ríkis eða sveitarfélaga og annars konar rekstrarformi tilheyrðu samtals 14,1\% fyrirtækjanna. Ef mið er tekið af flokkun Hagstofunnar á fyrirtækjum eftir rekstrarformi er ljóst að svörin eru skekkt par sem hlutfallslega flest fyrirtæki sem svöruðu könnuninni eru hlutafélög. Í skrá Hagstofunnar voru hlutafélög (almennings- og einkahlutafélög) 43,6\% og félagasamtök og sjálfseignarstofnanir fylgja par fast á eftir með 40,8\% hlutdeild (Hagstofa Íslands, 2005b).

Loks er pess að geta að um 10\% fyrirtækja í könnuninni störfuðu í frumvinnslu (landbúnaði eða sjávarútvegi), liðlega $27 \%$ í iðnaði og úrvinnslu og um 53\% í pjónustu af ýmsu tagi. Ef skipting fyrirtækja á atvinnugreinar er borin saman við skiptingu Hagstofunnar á fjölda fyrirtækja og félaga eftir atvinnugreinum 2002 kemur í ljós að frumvinnslufyrirtæki voru 4,4\% fyrirtækja og félaga, iðnfyrirtæki $11,8 \%$ og pjónustufyrirtæki 83,7\% af heildarfjölda (Hagstofa Íslands, 2005a). Pjónustufyrirtæki hafa pví minni svörun en aðrar atvinnugreinar miðað við heildarpýði.

Á pessu stigi liggja fyrir sérkenni fyrirtækjanna og peirra stjórnenda sem svöruðu könnuninni og pví er ekki úr vegi að kynna pær niðurstöður sem snúa að stjórnunaraðferðum og skipulagi fyrirtækja.

\section{$4 \quad$ Skipulag íslenskra fyrirtækja}

Skipulagsheildir styðjast við stjórnskipulag til að ná fram markmiðum og stefnu. Í stjórnskipulagi er fyrirkomulag aðgerða og vinnuferla formfest, t.d. eru boðleiðir skilgreindar sem og tengsl milli manna og deilda. Pá er tekin ákvörðun um hvers konar samræmingarkerfi skipulagið skuli byggjast á. Í stjórnskipulagi fyrirtækis eru eftirtalin atriði ákveðin (Daft, 2004, bls. 86; Runólfur Smári Steinpórsson, Marteinn Pór Arnar og Sigurður Arnar Jónsson, 1995, bls. 17; Runólfur Smári Steinpórsson, 2003, bls. 48-49):

- Hvaða valdabrautir og formleg samskipti skuli vera á milli starfsmanna fyrirtækis, p. á m. stigveldi og stjórnunarspönn.

- Hvaða starfsmenn skuli tilheyra hvaða deildum og hvaða deildaskipting skuli vera í fyrirtækinu.

- Hvaða kerfi, m.a. til upplýsingavinnslu og boðmiðlunar, skuli tryggja árangursrík samskipti og samræmingu í starfsemi fyrirtækisins. 
Margvíslegt stjórnskipulag stendur fyrirtækjum til boða og eru megindrættir peirra dregnir upp í skipuriti. Helstu skipulagsformin eru starfaskipulag (e. functional structure), afurðaskipulag (e. divisional structure), svæðisskipulag (e. geographical structure) og fléttuskipulag (e. matrix structure). Hér er ekki tóm til að fjalla ítarlega um einkenni pessara skipulagsforma í löngu máli en helstu einkenni eru pessi (Daft, 2004; Runólfur Smári Steinpórsson o.fl., 1995):

- Í starfaskipulagi er störfum sem eru sambærileg innan fyrirtækis raðað saman í viðeigandi deildir, t.d. að öll framleiðsla á sér eingöngu stað í framleiðsludeild. Pau störf sem flokkuð eru undir sömu deild lúta sama yfirstjórnanda. Petta skipulag hentar best í litlum eða meðalstórum fyrirtækjum sem framleiða tiltölulega fáar afurðir. Helsti kostur pessa skipulags er stærðarhagkvæmni og pað krefst stöðugs starfsumhverfis sem einkennist af lítilli óvissu.

- Afurðaskipulag dregur nafn sitt af pví að pað er grundvallað á peim afurðum sem fyrirtækið framleiðir eða peirri pjónustu sem pað veitir. Helstu einkenni pessa skipulags eru að um hverja afurð eða vöru er mynduð sérstök rekstrareining sem inniheldur alla pá aðgerðapætti sem nauðsynlegir eru til að framleiða afurðina. Slíkt fyrirkomulag er algengt í stórum fyrirtækjum sem framleiða margar vörutegundir. Kaupfélögin eru dæmi um slíkt skipulag en pau höfðu sérstakar rekstrareiningar um mjólkurafurðir, kjötvörur, verslun o.fl. Helsti kostur afurðaskipulagsins er mikil aðlögunarhæfni par sem pað er vel sýnilegt viðskiptavinum og getur vel tekist á við breytilegt umhverfi.

- Svæðisskipulag er algengast í stórum fyrirtækjum og pví svipar mjög til afurðaskipulagsins og eru kostirnir svipaðir. Svæðisskipulag á vel við pegar fyrirtæki vilja samræma starfsemi sjálfstæðra rekstrareininga og dótturfyrirtækja sem starfa á tilteknum svæðum.

- Fléttuskipulag felst í pví að nýta samtímis kosti starfa- og afurðaskipulags. Рað sem einkennir pað öðru fremur er að starfa- og afurðaskipulagið er notað jöfnum höndum pannig að valdabrautir fléttast. Skipulagið miðar að pví að auðvelda öll samskipti og samræmingu innan fyrirtækisins til að gera pví kleift að mæta ólíkum kröfum umhverfisins. Petta skipulag hentar best í flóknu og síbreytilegu umhverfi.

Í könnuninni var spurt hvort stjórnskipulag (skipurit) hefði verið sampykkt í fyrirtækinu. Alls hafði stjórnskipulag verið sampykkt í 154 fyrirtækjum (59\%) sem svöruðu könnuninni en í 106 fyrirtækjum hafði slíkt skipulag ekki verið sampykkt. Fyrirtæki með fleiri en 50 starfsmenn hafa oftar sampykkt stjórnskipulag en minni fyrirtæki. Pegar stuðst er við tveggja hlutfalla próf er munurinn marktækur $(p<0,01)$. Hið sama á við um háskólamenntaða stjórnendur sem mun oftar hafa hugað að formlegu skipulagi en stjórnendur með aðra menntun ( $\mathrm{p}<0,01)$. Hafa ber pó í huga að stjórnendur stærri fyrirtækja í könnuninni hafa flestir lokið framhaldsskóla- og háskólanámi. Ekki er sjáanlegur munur á pví hvort stjórnskipulag hafi verið sampykkt eftir staðsetningu fyrirtækja eða starfsgrein peirra.

Athyglisvert er að stjórnendur 175 fyrirtækja merkja við spurningu um hvert sé stjórnskipulag fyrirtækisins. Раð pýðir að í 21 fyrirtæki er skipulag við lýði sem ekki 
hefur verið sampykkt af stjórn viðkomandi fyrirtækis. Algengasta stjórnskipulagið í íslenskum fyrirtækjum er starfaskipulagið (sjá mynd 1). ${ }^{4}$ Liðlega $67 \%$ fyrirtækja er svar barst frá höfðu slíkt skipulag. Næstalgengasta skipulagsformið er fléttuskipulag $(17,7 \%)$. Um 7\% fyrirtækja hafa tekið upp afurðaskipulag og jafn mörg fyrirtæki hafa svæðisskipulag. Spurningalistinn heimilaði að tilgreina aðra skipulagsmöguleika en enginn stjórnandi valdi pann möguleika.

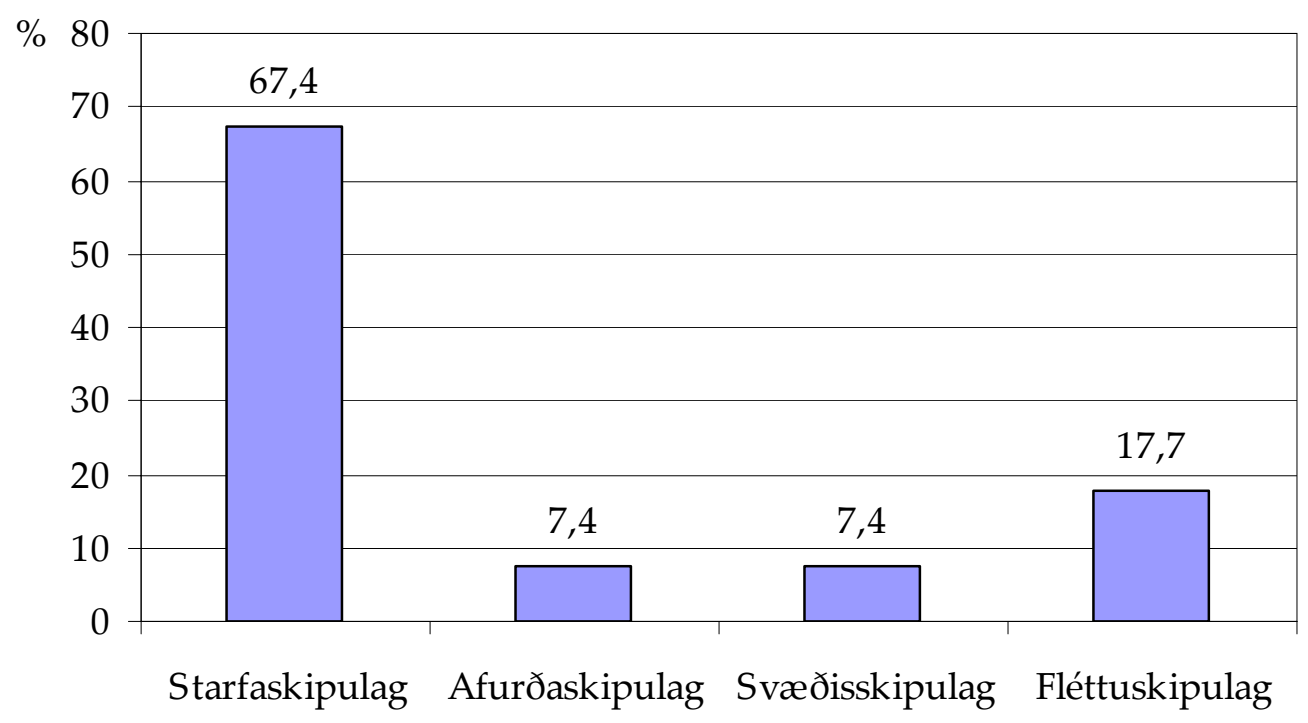

Mynd 1. Hvert er stjórnskipulag fyrirtækisins? n=175

Stærð fyrirtækja hefur áhrif á pau skipulagsform sem stjórnendur peirra velja (sjá

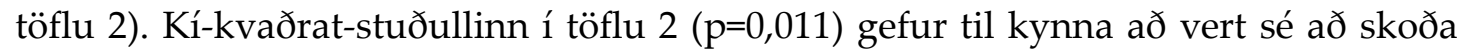
tengsl stærðar og skipulagsforms nánar. Fyrirtæki með færri en 50 starfsmenn eru líklegri til að skipuleggja starfsemi sína í anda starfaskipulags en stærri fyrirtæki. Munurinn er marktækur pegar borin eru saman hlutföll tveggja hópa $(\mathrm{p}=0,007)$. Eins eru stærri fyrirtæki líklegri til að velja fléttuskipulag en smærri. Munurinn er marktækur $(p=0,04)$. Sama verður hins vegar ekki sagt um aðrar gerðir skipulags par sem ekki kemur fram marktækur munur eftir starfsmannafjölda fyrirtækja.

\footnotetext{
${ }^{4}$ Ein spurning hljóðaði svo: Hvert er stjórnskipulag fyrirtækisins? Merkið við pá mynd sem best lýsir skipulaginu. Síðan fylgdu fjórar myndir sem eru dæmigerðar fyrir starfa-, afurða-, svæðis- og fléttuskipulag. Ef engin peirra átti við var mögulegt að merkja við annað og tilgreina skipulagið.
} 
Tafla 2. Stærð fyrirtækja og skipulagsform

\begin{tabular}{lcc}
\hline & $<50$ starfsmenn & $>50$ starfsmenn \\
\hline Starfaskipulag & $74,4 \%$ & $51,1 \%$ \\
Afurðaskipulag & $5,0 \%$ & $14,8 \%$ \\
Svæðisskipulag & $7,4 \%$ & $6,4 \%$ \\
Fléttuskipulag & $13,2 \%$ & $27,7 \%$ \\
\hline & $100,0 \%$ & $100,0 \%$ \\
\hline Kíl11,170, df=3 & & \\
$\mathrm{p}=0,011$ & & \\
\hline
\end{tabular}

Stjórnendur fyrirtækja og stofnana voru einnig spurðir um fjölda stjórnprepa í fyrirtækinu/stofnuninni. Samkvæmt könnuninni hafa íslensk fyrirtæki að meðaltali prjú stjórnprep (almenna starfsmenn, millistjórnendur og framkvæmdastjóra/ forstöðumann). Í nokkrum fyrirtækjum var einungis eitt stjórnprep en fimm pegar mest lét. Fjöldi stjórnprepa helst í hendur við fjölda starfsmanna. Рað er í samræmi við erlendar rannsóknir sem hafa leitt í ljós að fyrirtæki með 1.000 starfsmenn hafi allt að fjögur stjórnprep og að stjórnprepum fjölgi iðulega í sjö pegar starfsfólki fjölgi í 3.000 (Jones, 2004). Íslensk fyrirtæki falla pví vel að erlendu mynstri, p.e. að hafa allt að prjú til fjögur stjórnprep í skipulagsheildum með færri en 500 starfsmenn.

\section{Stjórnunaraðferðir}

\subsection{Almenn stjórnun}

Stjórnun er víðtækt hugtak sem nær yfir marga pætti. Upphaflega lögðu rannsakendur innan leiðtogafræða megináherslu á að rannsaka persónuleikaeinkenni (e. trait theory) árangursríkra stjórnenda. Síðar var lögð áhersla á að pjálfa stjórnendur og auka færni peirra (e. style-conselling). Að auki hefur verið bent á mikilvægi aðstæðubundinna pátta í stjórnun (e. contingency theory) og á liðnum árum hefur verið lögð mikil áhersla á náðarleiðtoga (e. charismatic leadership) eða umbreytingaleiðtoga (e. transformational leadership) (Ása Guðbjörg Guðfinnsdóttir, 2004; Bryman, 1996). Fræðimenn hafa jafnframt deilt um pað hvort ein stjórnunaraðferð henti best við allar aðstæður, eins og t.d. Rensis Likert heldur fram en hann telur að pátttökustjórnun og lýðræðisleg stjórnun skili bestum árangri óháð aðstæðum (sjá Bryman, 1996). Aðrir fræðimenn aðhyllast pað sjónarmið að stjórnun verði að henta aðstæðum hverju sinni og par má t.d. nefna Daniel Goleman, Paul Hersey og Kenneth Blanchard (Bryman, 1996; Goleman, 2000).

Í annarri fræðahefð hefur áhersla verið lögð á verkaskiptingu og hlutverk stjórnenda. Pannig lagði F. W. Taylor áherslu á ríka verkaskiptingu, stutta verkferla, aðgreiningu verkundirbúnings og vinnu og peningalega umbun (Taylor, 1997). Henry Fayol fjallaði hins vegar um hlutverk stjórnenda sem hann taldi felast í pví að spá fyrir um framtíðina, skipuleggja og gera áætlanir, gefa fyrirmæli og deila niður verkefnum, samhæfa aðgerðir og hafa eftirlit með starfsemi fyrirtækja (Buchanan og Huczynski, 2004). Á svipaðan hátt telur Henry Mintzberg (1998) að hlutverk stjórnenda felist í mannlegum samskiptum (hann sé táknrænn fulltrúi, leiðtogi og 
samstarfsaðili); upplýsingahlutverki (hann sé ábyrgðaraðili upplýsinga, miðli peim og sé talsmaður fyrirtækis út á við); og ákvarðanatöku (hann sé frumkvöðull, eigi að halda truflunum í lágmarki, úthluta gæðum og sé samningamaður). Hér er ekki tóm til að nefna alla pá sem hafa haft áhrif á rannsóknir á stjórnun en geta má Eltons Mayo (1997). Hann taldi rannsóknir sínar leiða í ljós mikilvægi hins óformlega kerfis í skipulagsheildum og mikilvægi vinnuhópa fyrir almenna starfsmenn. Í samræmi við pað lagði hann áherslu á að skapa góðan starfsanda með pví að hlustað sé á umkvartanir starfsfólks. Stjórnendur skulu pjálfaðir í pví að taka tillit til starfsfólks og hinu óformlega kerfi skal ekki útrýmt heldur skal pað sveigt að hinu formlega kerfi.

Ekki er auðvelt að spyrjast fyrir um stjórnunaraðferðir par sem um flókið fyrirbæri er að ræða. Til að nálgast viðfangsefnið með spurningalistaaðferð var stuðst við líkan Herseys og Blanchards (1988) um aðstæðubundna stjórnun (e. situational leadership). Ástæða pess er að pað er vel pekkt og auðvelt í framkvæmd. Peir telja að stjórnandi verði að velja stjórnunaraðferð sem henti aðstæðum hverju sinni, p.e. áhuga og hæfni starfsmanns til að leysa verkefni. Peir aðgreina fjórar stjórnunaraðferðir, en pær eru stýrandi, hvetjandi, veitandi og felandi stjórnun (sjá töflu 3).

Tafla 3. Hugmyndir Pauls Herseys og Kenneths Blanchards um aðstæðubundna stjórnun.

\begin{tabular}{|c|c|}
\hline $\begin{array}{l}\text { Stýrandi } \\
\text { - Lítill verkefnaproski og áhugi } \\
\text { starfsmanns } \\
\text { - Stjórnandi gefur nákvæm } \\
\text { fyrirmæli og fylgist grannt með } \\
\text { frammistöðu starfsmanna }\end{array}$ & $\begin{array}{l}\text { Hvetjandi } \\
\text { - } \text { Lítill eða miðlungsmikill } \\
\text { verkefnaproski, mikill áhugi } \\
\text { starfsmanns } \\
\text { - Stjórnandi veitir upplýsingar, } \\
\text { útskýrir, spyr og hvetur til dáða }\end{array}$ \\
\hline $\begin{array}{l}\text { Veitandi } \\
\text { - Miðlungsmikill eða mikill } \\
\text { verkefnaproski, e.t.v. lítill vilji } \\
\text { starfsmanns } \\
\text { - Stjórnandi veitir uppörvun, } \\
\text { stuðning og hvatningu, hvetur } \\
\text { til pátttöku }\end{array}$ & $\begin{array}{l}\text { Felandi } \\
\text { - Mikill verkefnaproski, mikill } \\
\text { áhugi starfsmanns } \\
\text { - Stjórnandi færir starfsmanni } \\
\text { vald til að vinna á eigin } \\
\text { forsendum, fylgist með } \\
\text { álengdar }\end{array}$ \\
\hline
\end{tabular}

Pegar stjórnendur voru spurðir um hvaða stjórnunaraðferðum peir beiti svöruðu 87 $(33,2 \%)$ að peir útskýri verkefni, láti starfsfólk vinna á eigin forsendum og fylgist 
með álengdar (felandi stjórnun). ${ }^{5}$ Álíka margir (32,4\%) veita starfsfólki nauðsynlegar upplýsingar, útskýra ákvarðanir, spyrja og hvetja starfsfólk til dáða (hvetjandi stjórnun). Meðal stjórnenda blanda 27,4\% saman ólíkum stjórnunaraðferðum (sjá mynd 2). Athygli vekur að innan við 3\% stjórnenda beita stjórnunarferðum í anda einvaldsstjórnunar, p.e. að segja starfsfólki nákvæmlega fyrir verkum og fylgjast vel með pví (stýrandi stjórnun).

Ekki er munur er á milli starfsgreina um hvaða stjórnunaraðferðir eru valdar af stjórnendum.

Menntun stjórnenda virðist hafa áhrif á val stjórnunaraðferða. Stjórnendur sem lokið hafa grunnskóla- og framhaldsskólanámi beita helst stýrandi og hvetjandi stjórnunaraðferðum, iðnmenntaðir stjórnendur nota mest veitandi og felandi stjórnun, á meðan að háskólamenntaðir stjórnendur velja allar aðferðir, nema stýrandi stjórnun, nær jöfnum höndum. Munurinn á milli grunnskóla- og framhaldsskólamenntaðra stjórnenda og annarra stjórnenda er marktækur pegar stuðst er við tveggja hlutfalla próf $(p<0,05)$.

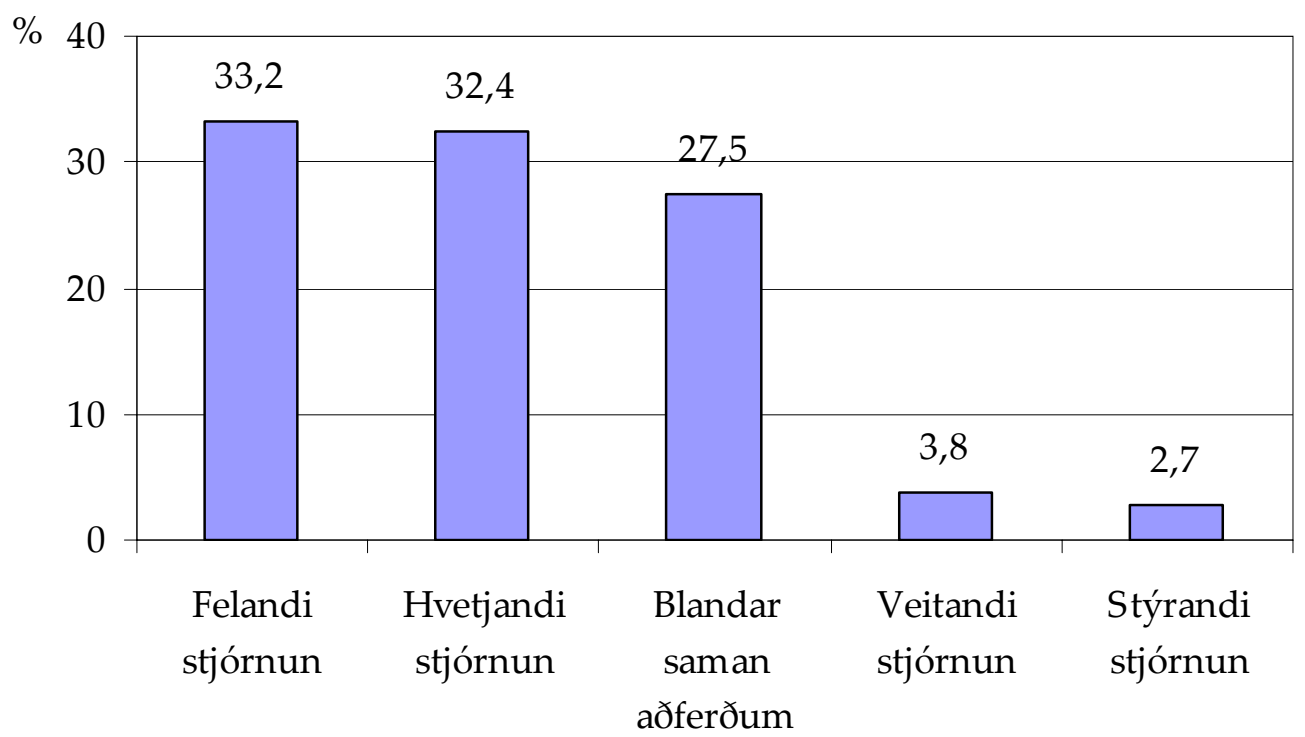

Mynd 2. Hvaða stjórnunaraðferðum beitir pú í starfi pínu sem stjórnandi? n=262

Fyrirtæki á Akureyri virðast velja stýrandi og hvetjandi stjórnun í ríkari mæli en fyrirtæki á höfuðborgarsvæðinu. Pau síðarnefndu velja frekar veitandi og felandi stjórnun (sjá töflu 4). Kí-kvaðrat-stuðullinn í töflu 4 gefur til kynna að vert sé að skoða pessi tengsl nánar. Munurinn er marktækur samkvæmt tveggja hlutfalla prófi $(\mathrm{p}=0,009)$. Fyrirtæki á landsbyggðinni skiptast nær jafnt á milli pessara aðferða.

5 Við spurningu um hvaða stjórnunaraðferðir stjórnendur beiti voru gefnir sex valmöguleikar. Hver stjórnunaraðferð var útskýrð nánar í orðum, t.d. „segi starfsfólki nákvæmlega hvernig og hvenær pað eigi að vinna störfin og fylgist vel með starfsfólki“. Рað er dæmi um stýrandi stjórnun. Auk peirra fjögurra stjórnunaraðferða samkvæmt Hersey og Blanchard var gefinn kostur á að merkja við að blanda saman aðferðum og ekkert af ofantöldu. 
Sérstaða Akureyrar skýrist að mestu með menntun stjórnenda en par eru hlutfallslega færri stjórnendur með iðn- eða háskólamenntun að baki en stjórnendur annars staðar á landinu. ${ }^{6}$

Tafla $4 . \quad$ Staðsetning fyrirtækja og stjórnunaraðferðir.

\begin{tabular}{|c|c|c|c|}
\hline & Höfuðborgin & Akureyri & Landsbyggðin \\
\hline Stýrandi* & $27,8 \%$ & $45,6 \%$ & $37,7 \%$ \\
\hline Felandi+ & $43,6 \%$ & $25,3 \%$ & $37,7 \%$ \\
\hline \multirow[t]{2}{*}{ Blandar saman } & $28,6 \%$ & $29,1 \%$ & $24,5 \%$ \\
\hline & $100,0 \%$ & $100,0 \%$ & $100,0 \%$ \\
\hline $\begin{array}{l}K_{i}^{\prime}=9,198, d f=4 \\
p=0,056\end{array}$ & & & \\
\hline
\end{tabular}

Skýringar:

* Stýrandi og hvetjandi stjórnun flokkuð saman.

+ Veitandi og felandi stjórnun flokkuð saman.

Stærð fyrirtækja og pað stjórnskipulag sem hefur verið valið innan peirra hefur engin sýnileg áhrif á pær stjórnunaraðferðir sem valdar eru.

\subsection{Liðsvinna}

Rannsóknir hafa leitt í ljós að liðsvinna geti aukið framleiðni, lækkað framleiðslukostnað og örvað nýsköpun. Enn fremur má nefna að hún er talin geta aukið ánægju viðskiptavina, starfsánægju, hollustu við fyrirtæki og gæði vöru og pjónustu (Zárraga og Bonance, 2003; Buchanan og Huczynski, 2004). Aukin alpjóðleg samkeppni og örar tæknibreytingar hafa pví ýtt undir vinsældir liðsvinnu innan stjórnunarfræðanna. Ein spurning í könnuninni laut að pví að spyrja um liðs- eða hópastarf í fyrirtækjum. Рað er mjög algengt í peim fyrirtækjum sem svöruðu könnuninni. Alls bárust 260 svör við peirri spurningu og stjórnendur í 186 fyrirtækjum (71,5\%) sögðu að liðs- eða hópastarf væri við lýði í fyrirtækinu. Liðsstarf var algengast í pjónustufyrirtækjum (73,3\%), pá í iðnaði $(70,4 \%)$ og loks í frumvinnslufyrirtækjum (57,7\%). Munurinn er ekki tölfræðilega marktækur.

Fyrirtæki á landsbyggðinni nota liðsstarf mest, en $82,4 \%$ svöruðu að pau nýti sér hópastarf, 73,8\% fyrirtækja á höfuðborgarsvæðinu og 60,3\% fyrirtækja á Akureyrarsvæðinu (sjá töflu 5). Kí-kvaðrat-stuðull í töflu 5 (p=0,017) gefur til kynna að um samband sé að ræða milli liðsstarfs og staðsetningar fyrirtækja. Munurinn er tölfræðilega marktækur pegar borin eru saman hlutföll hópa milli Akureyrar og landsbyggðarinnar $(p=0,004)$. Munurinn er hins vegar ekki marktækur milli höfuðborgarsvæðisins og landsbyggðarinnar eða milli höfuðborgarinnar og Akureyrar.

\footnotetext{
6 51,7\% stjórnenda á Akureyri höfðu einungis lokið grunnskóla eða framhaldsskóla í samanburði við um 20\% í Reykjavík eða á landsbyggðinni. Munurinn á menntun stjórnenda eftir staðsetningu er marktækur miðað við tveggja hlutfalla próf $(\mathrm{p}<0,05)$.
} 
Tafla 5.

Liðsstarf og staðsetning fyrirtækja.

\begin{tabular}{lccc}
\hline & Höfuðborgin & Akureyri & Landsbyggðin \\
\hline Liðsstarf & $73,8 \%$ & $60,2 \%$ & $82,3 \%$ \\
Ekki liðsstarf & $26,2 \%$ & $39,8 \%$ & $17,7 \%$ \\
\hline & $100,0 \%$ & $100,0 \%$ & $100,0 \%$ \\
\hline Kí $=8,093, \mathrm{df}=2$ & & & \\
$\mathrm{p}=0,017$ & & & \\
\hline
\end{tabular}

Fyrirtæki með fleiri en 50 starfsmenn nota liðsstarf í 87\% tilfella en minni fyrirtæki í $67 \%$ tilfella. Kí-kvaðrat-stuðull $(7,868, \mathrm{p}=0,005)$ hafnar núll-tilgátunni og munurinn er tölfræðilega marktækur pegar borin eru saman hlutföll tveggja hópa $(p>0,01)$. Liðsvinna virðist hins vegar ekki leiða til betri eða verri rekstrarafkomu fyrirtækja par sem enginn marktækur munur er á pví hvort fyrirtæki sem hafa tekið upp liðsstarf séu rekin með hagnaði eða tapi $(\mathrm{p}=0,6)$. Líkleg skýring á pví er að meirihluti fyrirtækja var rekinn með hagnaði árið 2003.

Við spurningu um hvers konar hópastarf sé í fyrirtækjum bárust svör frá 185 fyrirtækjum og par sem mögulegt var að merkja við fleiri en eitt svar bárust alls 307 svör. Verkefnalið (аð vinna í teymi að tilteknu verkefni) eru algengasta form hópastarfs og er раð аð finna í 57\% fyrirtækja. Pverfaglegir hópar, par sem fólk úr mismunandi deildum vinnur saman, eru einnig algengir en slíkir hópar eru við lýði í 39,5\% fyrirtækja og síðan koma framleiðsluhópar sem vinna að staðaldri saman í framleiðslu eða pjónustu (37,3\%). Umbótalið er að finna í um 16\% fyrirtækja og aðgerðahópa í 13\% fyrirtækja (sjá mynd 3).

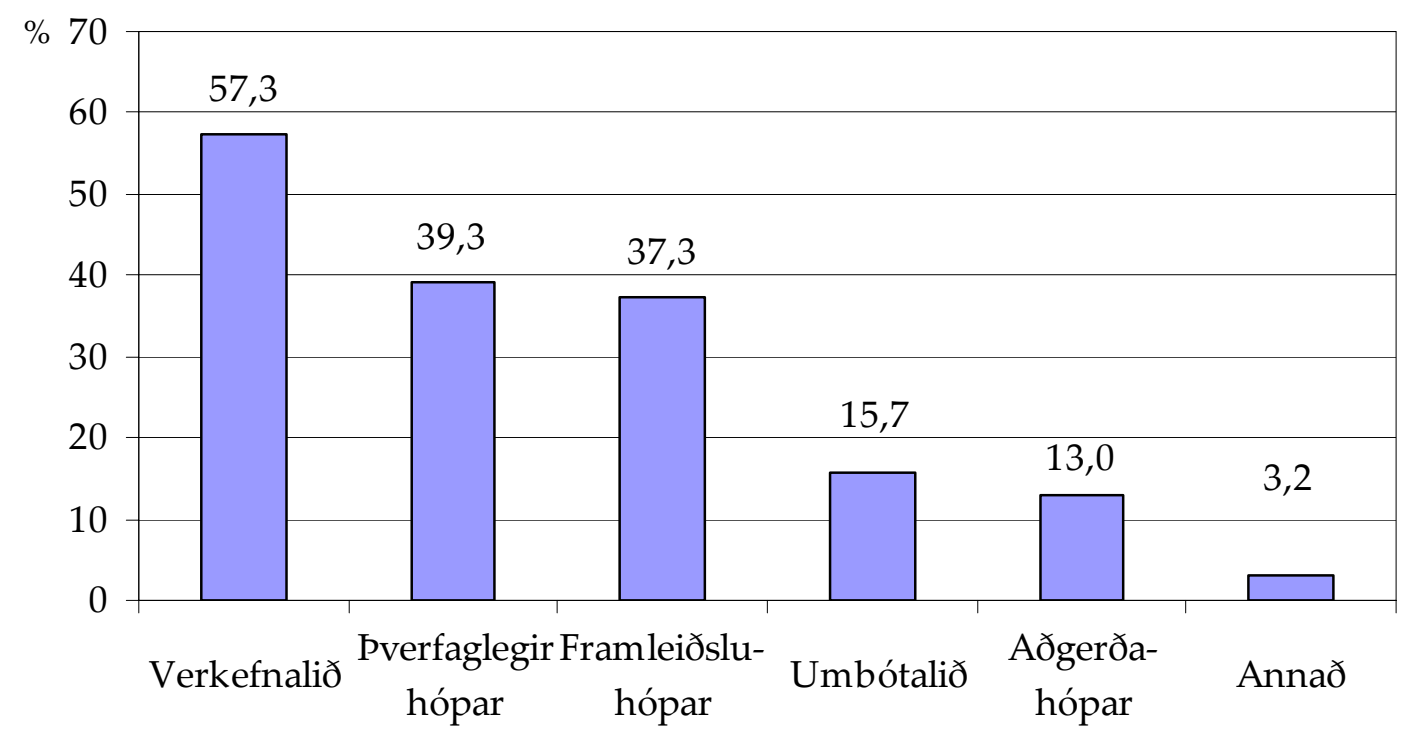

Mynd 3. Hvernig hópar eru við lýði í fyrirtækinu? Merkt við fleiri en eitt svar ef við á. $n=307$.

Af pví sem fram kemur hér að ofan er ljóst að liðsvinna er algeng í íslenskum fyrirtækjum. Раð á einkum við um stærri fyrirtæki á landsbyggðinni. 


\section{Samstarf fyrirtækja og útboð verkefna}

Breytingar í rekstrarumhverfi fyrirtækja, einkanlega aukin hnattvæðing, örar breytingar á mörkuðum og sífelldar tækninýjungar hafa leitt til breytinga í rekstri fyrirtækja. Annars vegar hafa pau leitast við að auka sveigjanleika í rekstri og hins vegar hafa pau tekið upp samstarf við önnur fyrirtæki. Margir stjórnendur fyrirtækja hafa kosið að auka sveigjanleika í rekstri til að öðlast aðlögunarhæfileika að markaðssveiflum með pví að fækka starfsfólki og millistjórnendum, auk pess að ráða inn tímabundið starfslið, svo sem hlutastarfsmenn, nema, verktaka og ráðgjafa. Pá hafa pau leitast við að bjóða út hluta af starfseminni til annarra fyrirtækja eða verktaka (Atkinson, 1987; Bell og Henry, 2001; Boswell o.fl., 2001; Littler og Innes, 2003). Ein afleiðing pess er að skipulag fyrirtækja hefur orðið flatara. Fyrirtæki hafa einnig tekið upp formlegt samstarf og samvinnu við önnur fyrirtæki, birgja og viðskiptavini til að auka hagnað, lækka kostnað og auka gæði. Markmiðið er að efla samkeppnisstöðu á alpjóðlegum markaði. Stjórnendur slíkra fyrirtækja hafa pannig purft að huga að samskiptum við samstarfsfyrirtæki, auk pess að stýra eigin fyrirtæki (Daft, 2004).

Í spurningalistanum var spurt um samstarf fyrirtækja og útboð verkefna. Alls höfðu 163 fyrirtæki af 262 (62,2\%) undirritað samning um formlegt samstarf við önnur fyrirtæki. Eins og sjá má af mynd 4 hafa um 20\% fyrirtækja gert samning um markaðs- og sölumál, liðlega 18\% hafa gert samning um dreifingu vöru og pjónustu og 14\% hafa undirritað samning við annað fyrirtæki um framleiðslu. Mögulegt var að merkja við fleiri en einn svarmöguleika.

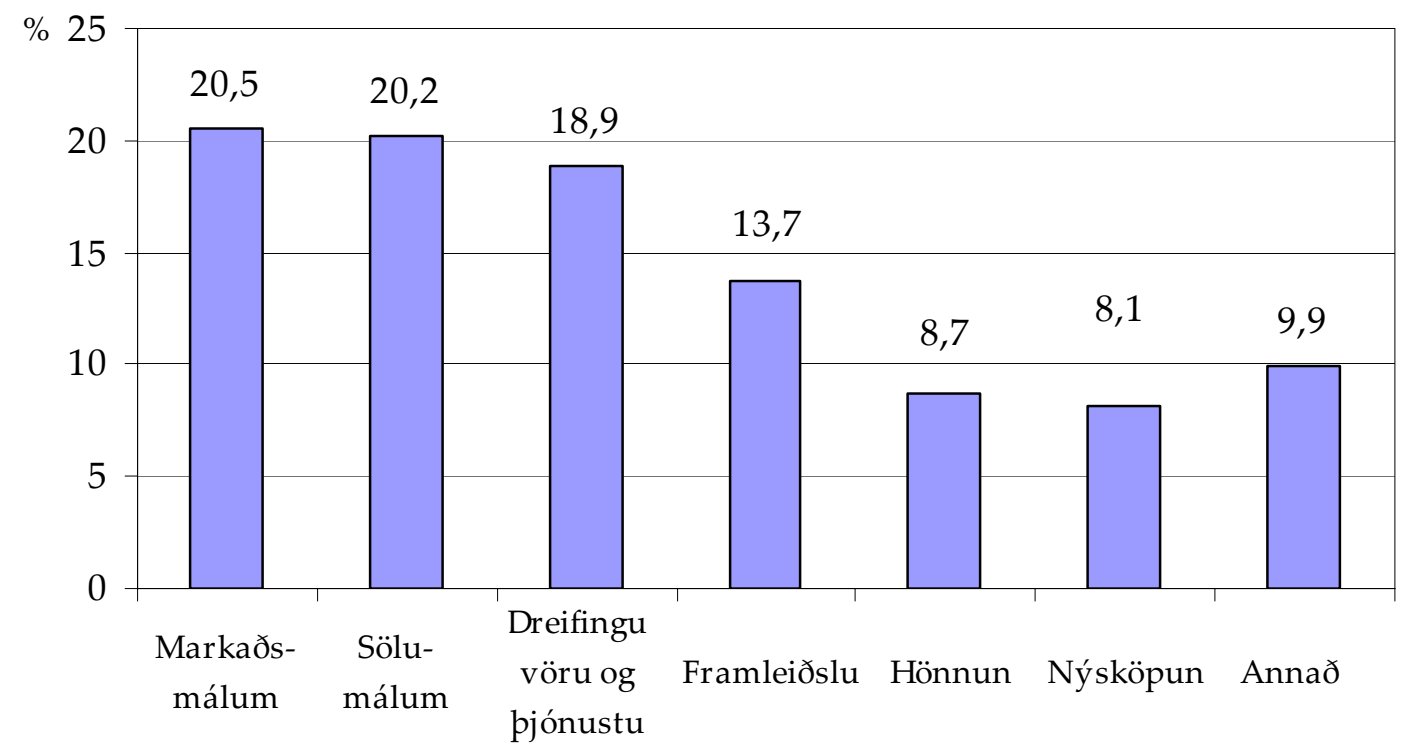

Mynd 4. Á hvaða sviðum hefur verið undirritaður samningur um formlegt samstarf við önnur fyrirtæki? Merkt við fleiri en eitt svar ef við á. $\mathrm{n}=322$.

Lítill munur er á milli starfsgreina og staðsetningar fyrirtækja hvað samstarf fyrirtækja varðar. Hins vegar er samstarfið hlutfallslega algengara í fyrirtækjum með fleiri en 50 starfsmenn en í minni fyrirtækjum: 73,6\% stærri fyrirtækja og 59,0\% minni fyrirtækja hafa innleitt samstarf. Kí-kvaðrat-stuðull $(3,785, p=0,052)$ bendir til pess að 
um samband sé að ræða. Sambandið á milli stærðar og samstarfs fyrirtækja er tölfræðilega marktækt miðað við tveggja hlutfalla próf $(\mathrm{p}=0,046)$.

Háskólamenntaðir stjórnendur efna marktækt oftar til samstarfs við önnur fyrirtæki en stjórnendur sem hafa annan menntabakgrunn (sjá töflu 6). Kí-kvaðratstuðull bendir til sambands $(\mathrm{p}=0,001)$ og er sá munur marktækur pegar borin eru saman hlutföll tveggja hópa $(\mathrm{p}<0,004)$, p.e. háskólamenntaðir stjórnendur og stjórnendur sem lokið hafa framhaldsskóla, háskólamenntaðir og iðnmenntaðir stjórnendur, og háskólamenntaðir stjórnendur og grunnskólamenntaðir stjórnendur.

Tafla 6.

Menntun stjórnenda og samstarf fyrirtækja.

\begin{tabular}{lcccc}
\hline & $\begin{array}{c}\text { Grunn- } \\
\text { skólanám }\end{array}$ & $\begin{array}{c}\text { Framhalds- } \\
\text { skólanám }\end{array}$ & Iðnnám & Háskólanám \\
\hline Samstarf & $43,8 \%$ & $50,0 \%$ & $46,8 \%$ & $72,8 \%$ \\
Ekki samstarf & $56,2 \%$ & $50,0 \%$ & $53,2 \%$ & $27,2 \%$ \\
\hline & $100,0 \%$ & $100,0 \%$ & $100,0 \%$ & $100,0 \%$ \\
\hline Kí $=17,374, \mathrm{df}=3$ & & & \\
$\mathrm{p}=0,001$ & & & \\
\hline
\end{tabular}

Spurningunni um útboð verkefna svöruðu 265 fyrirtæki. Af peim höfðu 105 (40,2\%) boðið út hluta af starfsemi sinni hin síðari ár. Af einstakri starfsemi er algengast að íslensk fyrirtæki hafi boðið út tölvumál, ræstingar og öryggisgæslu (sjá mynd 5). Undir liðnum annað má finna pætti eins og bókhald, flutninga, tryggingar, framleiðslu o.fl. Mögulegt var að merkja við fleiri en einn svarmöguleika.

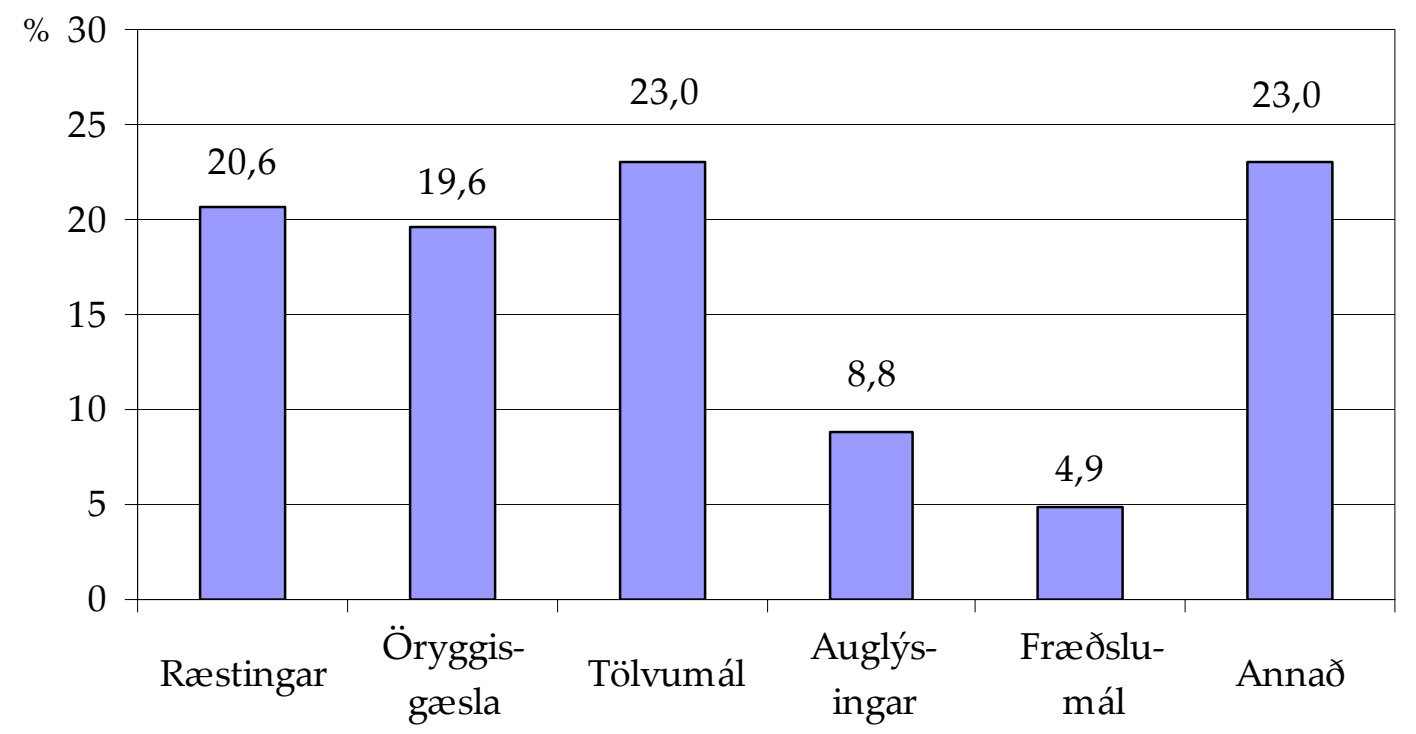

Mynd 5. Hvaða starfsemi hefur fyrirtækið boðið út á seinni árum? Merkt við fleiri en eitt svar ef við á. n=204.

Af töflu 7 má ráða að pað eru helst fyrirtæki á landsbyggðinni sem boðið hafa út hluta af starfsemi sinni, pví næst koma fyrirtæki á höfuðborgarsvæðinu og loks fyrirtæki á Akureyri og í nágrenni. Sambandið virðist ekki háð tilviljun samkvæmt kí-kvaðrat-stuðli $(\mathrm{p}=0,011)$ og er munurinn tölfræðilega marktækur miðað við tveggja hlutfalla próf $(\mathrm{p}<0,05)$. Fyrirtæki með fleiri en 50 starfsmenn bjóða nær 
helmingi oftar út starfsemi sína, hlutfallslega séð, en minni fyrirtæki $(60,4 \%$ samanborið við 33,7\%). Sá munur er tölfræðilega marktækur ( $p=0,001)$ miðað við tveggja hlutfalla próf.

Tafla 7. Útboð verkefna og staðsetning fyrirtækja.

\begin{tabular}{lccc}
\hline & Höfuðborgin & Akureyri & Landsbyggðin \\
\hline Útboð & $38,4 \%$ & $30,8 \%$ & $56,5 \%$ \\
Ekki útboð & $61,6 \%$ & $69,2 \%$ & $43,4 \%$ \\
\hline & $100,0 \%$ & $100,0 \%$ & $100,0 \%$ \\
\hline Kí =9,000, df=2 & & \\
$\mathrm{p}=0,011$ & & & \\
\hline
\end{tabular}

Athyglisvert er að menntun stjórnenda virðist hafa áhrif á ákvörðun um að bjóða út starfsemi fyrirtækja. Pannig eru útboð verkefna prisvar sinnum algengari í fyrirtækjum sem háskólamenntaðir stjórnendur stýra en í fyrirtækjum sem stjórnað er af iðnmenntuðum stjórnendum (sjá töflu 8). Kí-kvaðrat-stuðull $(\mathrm{p}=0,001)$ gefur til kynna að vert sé að skoða pað samband nánar. Munur á menntun stjórnenda og útboðum verkefna er tölfræðilega marktækur miðað við hlutföll tveggja hópa $(\mathrm{p}<0,02)$. Hafa ber í huga pað sem fyrr segir um að háskólamenntaðir stjórnendur eru líklegri en aðrir stjórnendur til að stýra stærri fyrirtækjum.

Tafla 8.

Menntun stjórnenda og útboð verkefna.

\begin{tabular}{lcccc}
\hline & $\begin{array}{c}\text { Grunn- } \\
\text { skólanám }\end{array}$ & $\begin{array}{c}\text { Framhalds- } \\
\text { skólanám }\end{array}$ & Iðnnám & Háskólanám \\
\hline Útboð & $25,0 \%$ & $33,3 \%$ & $16,7 \%$ & $51,7 \%$ \\
Ekki útboð & $75,0 \%$ & $66,7 \%$ & $83,3 \%$ & $48,3 \%$ \\
\hline & 100,0 & 100,0 & 100,0 & 100,0 \\
\hline Kí=21,697, df=3 & & & \\
$\mathrm{p}=0,001$ & & & \\
\hline
\end{tabular}

Útboð verkefna hefur engin áhrif á rekstrarárangur fyrirtækjanna og enginn sýnilegur munur er á pví í hvaða atvinnugrein fyrirtækin starfa með tilliti til útboða verkefna.

\section{Rekstrarárangur}

Stjórnunaraðferðir eru mikilvægar fyrir rekstur og afkomu fyrirtækja eins og fyrr segir. Stjórnun hefur áhrif á starfsánægju, frammistöðu og framleiðni starfsfólks, liðsvinnu, starfsmannaveltu og rekstrarárangur fyrirtækja (Griffin, 2002; Huzcynski og Buchanan, 2004; Kreitner, 2004; Mullins, 2005).

Athyglisvert er að kanna hvort stjórnunaraðferðir og skipulag hafi áhrif á rekstrarárangur fyrirtækjanna í könnuninni. Meirihluti fyrirtækja er svöruðu könnuninni, eða 171, (65,5\%) var rekinn með hagnaði árið 2003, 57 (22\%) voru rekin með tapi og 30 (11,5\%) á núlli (sjá mynd 6). Hlutfall fyrirtækja sem rekin voru með tapi var sjö prósentustigum lægra en árið á undan. Séu pessar niðurstöður yfirfærðar á pýðið er ekki hægt að fullyrða að breyting hafi átt sér stað milli ára. 


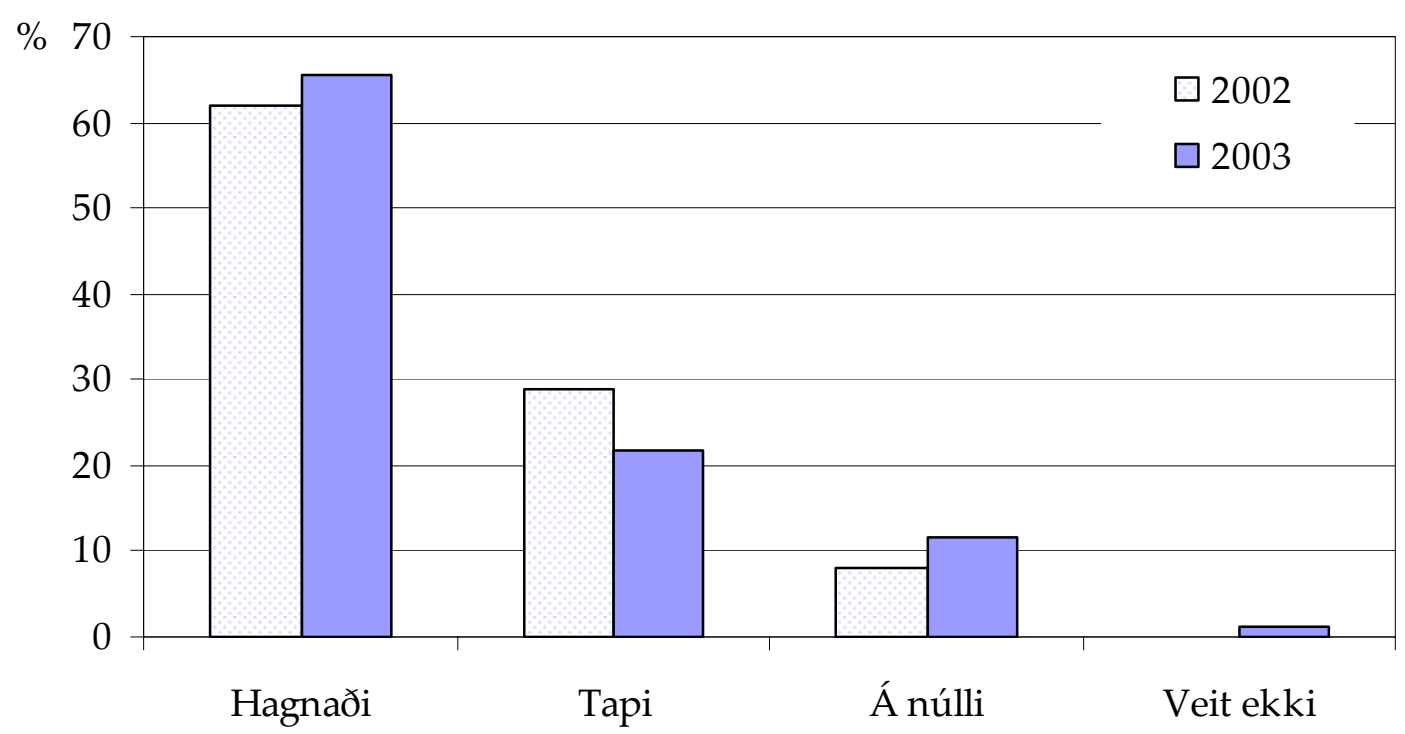

Mynd 6. Rekstrarafkoma fyrirtækja í könnuninni 2002 og 2003.

Stærð fyrirtækja virðist ekki hafa áhrif á afkomu peirra og ekki heldur landfræðileg staðsetning. Afkoma fyrirtækja er hins vegar ólík eftir starfsgreinum. Besta afkoman er í frumvinnslugreinum og iðnaði en nokkru slakari í pjónustufyrirtækjum. Munurinn á frumvinnslufyrirtækjum og pjónustufyrirtækjum er marktækur pegar hlutföll tveggja hópa eru borin saman $(\mathrm{p}=0,005)$ en pað á ekki við um mun á milli frumvinnslu- og iðnfyrirtækja eða iðnfyrirtækja og pjónustufyrirtækja. Stjórnunaraðferðir, liðsvinna, skipulagsform eða útboð verkefna hafa ekki áhrif á rekstrarárangur fyrirtækjanna í könnuninni. Menntun stjórnenda virðist hins vegar hafa áhrif á árangur fyrirtækjanna. Athyglisvert er að hlutfallslega skila stjórnendur með framhaldsskólamenntun bestum árangri en grunnskólamenntaðir stjórnendur slökustum árangri. Kí-kvaðrat-stuðull í töflu $9(\mathrm{p}=0,027)$ gefur til kynna að sambandið sé ekki háð tilviljun. Munurinn á milli rekstrarárangurs framhaldsskólamenntaðra stjórnenda og stjórnenda með aðra menntun er marktækur miðað við tveggja hlutfalla próf $(p<0,02)$. Hins vegar ber að varast að draga of víðtækar ályktanir af pví par sem líklegt er að aðrir stjórnendur séu í fyrirtækjunum sem hafi aðra menntun og auk pess eru um $20 \%$ fyrirtækja í könnuninni fyrirtæki sem ekki stefna að hagnaði. Pá eru margir pættir sem hafa áhrif á rekstrarárangur, svo sem skattamál, hráefnisverð, samkeppnisstaða o.fl. 
Tafla 9. Menntun stjórnenda og rekstrarárangur.

\begin{tabular}{lcccc}
\hline & $\begin{array}{c}\text { Grunn- } \\
\text { skólanám }\end{array}$ & $\begin{array}{c}\text { Framhalds- } \\
\text { skólanám }\end{array}$ & Iðnnám & Háskólanám \\
\hline Hagnaður & $47,1 \%$ & $81,3 \%$ & $57,4 \%$ & $65,5 \%$ \\
Ekki hagnaður & $52,9 \%$ & $18,8 \%$ & $42,6 \%$ & $34,5 \%$ \\
\hline & 100,0 & 100,0 & 100,0 & 100,0 \\
\hline
\end{tabular}

$\mathrm{Ki}=9,202, \mathrm{df}=3$

$\mathrm{p}=0,027$

Af pví sem fram kemur hér að framan er ljóst að stjórnunaraðferðir eða skipulag virðast ekki hafa áhrif á rekstrarárangur fyrirtækjanna sem svöruðu könnuninni. Рað er mjög athyglisvert og petta atriði parf frekari rannsókna við.

\section{$8 \quad$ Niðurstöður}

Samkvæmt rannsókninni hafa 154 fyrirtæki (59\%) sampykkt stjórnskipulag (skipurit). Fyrirtæki með fleiri en 50 starfsmenn og háskólamenntaða stjórnendur höfðu frekar sampykkt stjórnskipulag en önnur fyrirtæki. ${ }^{7}$

Starfaskipulag er algengasta skipulagsformið í íslenskum fyrirtækjum og 67\% fyrirtækjanna kváðust hafa slíkt skipulag. Næstalgengasta formið er fléttuskipulag $(17,7 \%)$, um $7 \%$ fyrirtækja hafa tekið upp afurðaskipulag og jafn mörg fyrirtæki hafa svæðisskipulag. Fyrirtæki með færri en 50 starfsmenn skipuleggja starfsemi sína í anda starfaskipulags í ríkari mæli en stærri fyrirtæki, sem eru líklegri til að hafa fléttuskipulag.

Íslensk fyrirtæki hafa að meðaltali prjú stjórnprep. Fjöldi stjórnprepa helst í heldur við fjölda starfsmanna í fyrirtækjum.

Stjórnendur í könnuninni beita felandi stjórnun í 33\% tilvika, álíka margir styðjast við hvetjandi stjórnun og $27 \%$ blanda saman ólíkum stjórnunaraðferðum. Fyrirtæki á Akureyri velja stýrandi og hvetjandi stjórnun í ríkari mæli en fyrirtæki á höfuðborgarsvæðinu.

Alls kváðust 186 fyrirtæki (71,5\%) vera með liðs- eða hópastarf í starfsemi sinni. Fyrirtæki á landsbyggðinni nota liðsstarf mest, pá fyrirtæki á höfuðborgarsvæðinu og loks á Akureyri og í nágrenni. Fyrirtæki með fleiri en 50 starfsmenn nota liðsvinnu oftar en fyrirtæki með færri starfsmenn. Verkefnalið er að finna í 57\% fyrirtækjanna, pverfaglega hópa í 39\% peirra og framleiðsluhópa í 37\% peirra og aðgerðahópa í $13 \%$ peirra.

Alls höfðu 163 fyrirtæki í könnuninni (62\%) undirritað samning um formlegt samstarf við önnur fyrirtæki, aðallega um markaðs- og sölumál, dreifingu vöru og pjónustu og um framleiðslu. Menntun stjórnenda hafði áhrif í pessu tilliti par sem háskólamenntaðir stjórnendur efna oftar til samstarfs við önnur fyrirtæki en aðrir stjórnendur. Stærri fyrirtæki eru líklegri til að hafa formlegt samstarf en minni fyrirtæki.

\footnotetext{
${ }^{7}$ Aðeins verður hér getið um pær niðurstöður sem eru tölfræðilega marktækar miðað við 5\% öryggismörk og tveggja hlutfalla próf.
} 
Af peim fyrirtækjum sem svöruðu könnuninni höfðu 105 (40\%) boðið út hluta af starfsemi sinni. Algengast var að boðin væru út tölvumál, ræstingar og öryggisgæsla. Раð eru helst landsbyggðarfyrirtæki sem hafa boðið út hluta af starfsemi sinni, pá fyrirtæki í Reykjavík og nágrenni en síst á Akureyri. Stærri fyrirtæki og fyrirtæki með háskólamenntaða stjórnendur bjóða einnig frekar út verkefni en hin.

Meirihluti fyrirtækjanna sem svaraði könnuninni (65\%) var rekinn með hagnaði árið 2003. Frumvinnslufyrirtæki skiluðu oftar hagnaði en pjónustufyrirtæki. Framhaldsskólamenntaðir stjórnendur skiluðu oftar hagnaði en stjórnendur með aðra menntun en túlka ber pær niðurstöður með varúð par sem margir pættir hafa áhrif á hagnað fyrirtækja. Stjórnunaraðferðir og skipulag fyrirtækja virðast ekki hafa áhrif á rekstrarárangur.

Hér verða helstu niðurstöður dregnar saman í samræmi við rannsóknarspurningar:

- Staðsetning fyrirtækja á landinu hafði aðeins áhrif á notkun liðsvinnu og útboð verkefna.

- Ekki hafði marktæk áhrif á stjórnunaraðferðir eða skipulag fyrirtækja í hvaða starfsgrein pau störfuðu en rekstrarafkoma er betri frumvinnslufyrirtækjum en pjónustufyrirtækjum.

- Stærð fyrirtækjanna hafði hins vegar mjög mikil áhrif á marga pætti stjórnunaraðferða og skipulags. Stærri fyrirtækin hafa oftar sampykkt stjórnskipulag, eru skipulögð í anda fléttuskipulags, hafa prjú eða fleiri stjórnprep, nota liðsvinnu oftar en minni fyrirtækin og hafa oftar boðið út hluta af starfsemi sinni.

- Háskólamenntaðir stjórnendur virðast beita öðrum stjórnunaraðferðum en stjórnendur með aðra menntun. Peir eru líklegri til að beita sér fyrir pví að stjórnskipulag hafi verið sampykkt, peir taka engan stjórnunarstíl fram yfir annan, ef einvaldsstjórnun er undanskilin, peir efna oftar til samstarfs við önnur fyrirtæki og peir eru líklegri en aðrir til að bjóða út hluta af starfsemi fyrirtækja sinna. Framhaldsskólamenntaðir stjórnendur skila hins vegar hlutfallslega bestum rekstrarárangri.

- Engin sjáanleg tengsl voru á milli stjórnunaraðferða og rekstrarárangurs. Helsta skýring pess er að mikill meirihluti fyrirtækja skilaði hagnaði árið 2003.

\section{Almenn umræða}

\subsection{Dýđing niðurstaðna fyrir stjórnendur}

Niðurstöður rannsóknarinnar gætu gagnast stjórnendum á Íslandi með ýmsu móti svo sem:

- $\quad$ Pær gefa til kynna hvernig íslensk fyrirtæki eru í samanburði við alpjóðleg stórfyrirtæki sem tekið hefur verið mið af í innlendu viðskiptanámi til pessa.

- $\quad$ Stjórnendur geta borið sig saman við niðurstöður í viðkomandi starfsgrein og pau fyrirtæki sem standa sig best. Pannig er mögulegt að nota könnunina sem hagnýtt viðmið (e. benchmarking) í starfi fyrirtækja. 
- Taka parf mið af menntun stjórnenda. Svo virðist sem stúdentspróf og háskólamenntun hafi áhrif á marga pætti stjórnunar og skili fyrirtækjum betri rekstrarárangri en ella. Forráðamenn fyrirtækja purfa pví að gefa menntun stjórnenda gaum í framtíðinni.

\subsection{Fræðilegt framlag og frekari rannsóknir}

Niðurstöður könnunarinnar eru um margt áhugaverðar par sem heildstæða vitneskju hefur skort á pessu sviði á Íslandi. Samanburður við fyrri innlendar niðurstöður er pví erfiður nema að hluta til. Hins vegar er mögulegt að bera niðurstöðurnar saman við erlendar rannsóknir. Almennt virðist sem stjórnendur á Íslandi velji sér skipulag og stjórnun í samræmi við pað sem tíðkast erlendis og kennt er í viðskiptanámi. Pannig velja stjórnendur helst starfaskipulag, sem hentar litlum fyrirtækjum með fáar framleiðsluvörur, en stærri fyrirtæki velja sér fremur fléttuskipulag. Ваð er í samræmi við pað sem erlendir fræðimenn telja ákjósanlegt (Jones, 2004; Daft, 2004).

Íslenskir stjórnendur velja helst felandi stjórnun og hvetjandi stjórnun, auk pess að blanda saman aðferðum. Erlendis takast fræðimenn á um pað hvort ein stjórnunaraðferð henti best við allar aðstæður, t.d. lýðræðisleg stjórnun (sjá Bryman, 1996), en aðrir aðhyllast pað sjónarmið að stjórnun verði að henta aðstæðum hverju sinni (Goleman, 2000; Bryman, 1996). Stjórnunaraðferðir íslenskra stjórnenda gefa til kynna að peir hallist að síðara sjónarmiðinu og peir blanda gjarnan saman aðferðum.

Niðurstöður varðandi menntun stjórnenda, sérstaklega að framhaldsskólapróf skuli vera hlutfallslega hagnýtast, eru í samræmi við rannsóknir í anda mannauðsumræðunnar (Schultz, 1961; Becker, 1992). Par kemur fram að fjárfesting í framhaldsskólamenntun skilar bæði einstaklingum og pjóðfélagi hvað mestum ávinningi.

Frekari rannsókna er pörf á stjórnunaraðferðum og skipulagi íslenskra fyrirtækja. Pannig væri áhugavert að endurtaka rannsóknina til að kanna hvort hún lýsi íslenskum fyrirtækjum almennt eða aðeins hluta peirra. Einnig væri fengur í að hafa samanburð milli ára og mikill fengur væri í að kafa dýpra ofan í einstaka pætti rannsóknarinnar með viðtölum og vinnustaðagreiningu. Pá væri áhugavert að gera tilraun á tengslum stjórnunaraðferða og rekstrarárangurs.

\subsection{Takmarkanir rannsóknar}

Allar rannsóknir eru takmörkunum háðar. Í pessari rannsókn má segja að lágt svarhlutfall dragi úr peirri vissu sem hægt er að álykta með út frá niðurstöðum. Til málsbóta má pó telja að úrtakið var lagskipt og endurspeglar pannig nokkuð vel heildarpýði. Með pví að bera pau fyrirtæki sem svöruðu könnuninni við upplýsingar um einkenni íslenskra fyrirtækja frá Hagstofu Íslands virðast helstu skekkjur vera pær að peir sem pátt tóku í könnuninni stýrðu stærri einkahlutafélögum í frumvinnslu og iðnaði en meðaltal íslenskra fyrirtækja geftur til kynna. Pá má nefna að niðurstöður byggja aðallega á nafnabreytum og pað kallar á varfærni við að yfirfæra niðurstöður yfir á íslensk fyrirtæki almennt séð. 


\section{Lokaorð}

Í pessari grein var fjallað um rannsókn á skipulagi og stjórnunaraðferðum í íslenskum fyrirtækjum. Markmið hennar var í fyrsta lagi að kanna hvaða skipulagsform (skipurit) eru við lýði í íslenskum fyrirtækjum. Í öðru lagi var markmiðið að kanna hvaða stjórnunaraðferðir eru algengastar í íslenskum fyrirtækjum og í priðja lagi að athuga hvort fyrirtækin hafi boðið út verkefni og tekið upp formlegt samstarf við önnur fyrirtæki. Meðal rannsóknarspurninga sem reynt var að svara eru t.d. hvort munur sé á stjórnunaraðferðum og skipulagi milli fyrirtækja á höfuðborgarsvæðinu og landsbyggðinni, eftir starfsgreinum og hvort rekstrarárangur sé ólíkur eftir pví hvaða stjórnunaraðferðum fyrirtækin beiti.

Niðurstöður benda til að staðsetning fyrirtækja á landinu og starfsgrein fyrirtækja hafi óveruleg áhrif á stjórnun eða skipulag peirra. Stærð fyrirtækja og menntun stjórnenda hafði hins vegar mjög mikil áhrif á marga pætti stjórnunar og skipulags. Engin sjáanleg tengsl voru á milli stjórnunaraðferða og rekstrarárangurs. Helsta skýring pess er að mikill meirihluti fyrirtækja skilaði hagnaði árið 2003. Pörf er á frekari rannsóknum á stjórnunaraðferðum og skipulagi til að efla íslenskt atvinnulíf og tryggja varanlegan árangur fyrirtækja.

\section{Heimildir}

Aaker, D. A.; Kumar, V. og Day, G. S. (2001). Marketing Research (7. útgáfa). New York: John Wiley \& Sons.

Atkinson, J. (1987). Flexibility or fragmentation? The United Kingdom labour market in the eighties. Labour and Society, 12, 87-105.

Árelía Eydís Guðmundsdóttir (2005). Hefur viðhorf millistjórnenda áhrif á árangur peirra í starfi? Í Ingjaldur Hannibalsson (ritstj.). Rannsóknir í félagsvísindum VI. Erindi flutt á ráđstefnu í október 2005. Reykjavík: Félagsvísindadeild Háskóla Íslands og Háskólaútgáfan.

Árelía Eydís Guðmundsdóttir (2002): Íslenskur vinnumarkaður á umbrotatímum: Sveigjanleiki skipulagsheilda, stjórnun og endurskipulagning efnahagslífsins. Reykjavík: Háskólinn í Reykjavík.

Arney Einarsdóttir (2004). Áhrifavaldar starfsánægju og hvatningar: Íslensk stöðlun og prófun á evrópsku starfsánægjuvísitölunni. Reykjavík: Viðskipta- og hagfræðideild Háskóla Íslands. Meistaraprófsritgerð.

Ása Guðbjörg Ásgeirsdóttir (2004). Stjórnunarstill, trú stjórnenda á eigin stjórnunarfærni og viðhorf undirmanna til starfs sins og vinnuumhverfis. Reykjavík: Viðskipta- og hagfræðideild Háskóla Íslands. Meistaraprófsritgerð.

Ásta Björnsdóttir, Finnur Oddsson, Hafsteinn Bragason, Inga Jóna Jónsdóttir og Tómas Bjarnason (2004). Könnun Cranet samstarfsins á mannauðsstjórnun í íslenskum fyrirtækjum og stofnunum 2003. Reykjavík: IMG-Gallup og Háskólinn í Reykjavík.

Becker, G. S. (1992). Human Capital and the Economy. Proceedings of the American Philosophical Society, 136 (1): 85-92. 
Bell, S. A. og Henry, J. F. (2001). Are employment relations undergoing a fundamental change that threatens the future of capitalism? A critique of Hodgson's view of the labour contract. Journal of Economic Issues, 35 (2), 335-343.

Boswell, W. R.; Moynihan, L. M.; Roehling, M. V. og Cavanaugh, M. A. (2001). Responsibilities in the "new employment relationship": An empirical test of an assumed phenomenon. Journal of Managerial Issues, 13 (3), 307-327.

Bryman, A. (1996). Leadership in organizations. Í Clegg, S. W.; Hardy, C. og Nord, W. R. (ritstj.), Handbook of Organization Studies. London: Sage Publications.

Burns, A. C. og Bush, R. F. (2003). Marketing Research: Online research applications. Upper Saddle River, N.J.: Prentice Hall.

Churchill, G. A. (2002). Marketing Research: Methodological foundations. Fort Worth: Harcourt College Publishers.

Daft, R. F. (2004). Organization Theory and Design (8. útgáfa). Mason: South-Western.

Griffin, R. W. (2002). Management (7. útgáfa). Boston: Houghton Mifflin Company.

Goleman, D. (2000). Leadership that gets results. Harvard Business Review, 78 (2), 7890.

Hagstofa Íslands (2005a). Fjöldi launagreiðenda eftir starfsmannafjölda, landsvæðum og atvinnugreinum 1998-2003. Sótt 15. janúar 2005 af

http://www.hagstofan.is/template $1 \mathrm{~b}$ frameset.asp?PageID=311\&intPXCatID=176\&if $\underline{\text { rmsrc }=/ \text { temp/fyrirtaeki/fjoldi.asp. }}$.

Hagstofa Íslands (2005b). Fjöldi skráðra fyrirtækja og félaga eftir rekstrarformi 1999_ 2003. Sótt 17. janúar 2005 af

http://www.hagstofan.is/template $\mathrm{db}$ frameset.asp?PageID=1285\&ifrmsrc=/uploads/ files/LH04/L040401.xls.

Harpa Björg Guðfinnsdóttir og Inga Jóna Jónsdóttir (2005). Próun stjórnendahæfni í litlum og meðalstórum fyrirtækjum. Í Ingjaldur Hannibalsson (ritstj.). Rannsóknir í félagsvísindum VI. Erindi flutt á ráðstefnu í október 2005. Reykjavík:

Félagsvísindadeild Háskóla Íslands og Háskólaútgáfan.

Hersey, P. og Blanchard, K. H. (1988). Management of organizational behavior: Utilizing Human Resources. Englewood Cliffs, N.J.: Prentice Hall.

Buchanan, D. og Huczynski, A. (2004): Organizational Behaviour (5. útgáfa). London: Prentice Hall.

Inga Hanna Guðmundsdóttir og Árelía Eydís Guðmundsdóttir (2005). Vongóðir millistjórnendur og samræming vinnu og einkalífs. Í Ingjaldur Hannibalsson (ritstj.). Viðskipta- og hagfræðideild. Rannsóknir í félagsvísindum VI. Erindi flutt á ráðstefnu í október 2005. Reykjavík: Félagsvísindadeild Háskóla Íslands og Háskólaútgáfan.

Ingi Rúnar Eðvarðsson (2005). Er pekkingarstjórnun viðhafnarinnar virði? Niðurstöður alpjóðlegra kannana. Í Ingjaldur Hannibalsson (ritstj.). Rannsóknir í félagsvísindum VI. Erindi flutt á ráđstefnu í október 2005. Reykjavík: Félagsvísindadeild Háskóla Íslands og Háskólaútgáfan. 
Ingi Rúnar Eðvarðsson (2004). Dekkingarstjórnun. Akureyri: Háskólinn á Akureyri.

Jones, G. R. (2004). Organizational theory, design, and change. Text and cases (4. útgáfa). Upper Saddle River: Prentice Hall.

KPMG Consulting (2000). Knowledge Management Research Report 2000. Annapolis/London: Höfundur.

Kreitner, R. (2004). Management (9. útg.). Boston: Houghton Mifflin Company.

Lim, K. K. og Ahmed, P. K. (2000). Enabling knowledge management: a measurement perspective. ICMIT 2000. Sótt 14. apríl 2004 af http://ieeexplore.ieee.org/iel5/7328/19806/00916781.pdf.

Littler, C. R. og Innes, P. (2003): Downsizing and deknowledging the firm. Work, Employment and Society, 17 (1), 73-100.

Malhrota, N. K. og Birks, D. F. (2003). Marketing research: An applied approach. Harlow: Prentice Hall.

Mayo, E. (1997). Hawthorne and the Western Electric Company. Í Pugh, D. S. (ritstj.). Organization theory: Selected readings. London: Penguin Books.

Mintzberg, H. (1998). The manager's job: Folklore and fact. Í Harvard Business Review on Leadership, 1-36.

Mullins, L. J. (2005). Management and Organisational Behaviour (7. útgáfa). Harlow: Prentice Hall.

Nilsson, F. og Kald, M. (2002). Recent Advances in Performance Management: The Nordic Case. European Management Journal, 20 (3), 235-245.

Runólfur Smári Steinpórsson, Marteinn Pór Arnar, Sigurður Arnar Jónsson (1995). Skipulag fyrirtækja. Reykjavík: Framtíðarsýn hf.

Runólfur Smári Steinpórsson (2003). Stefnumiðuð stjórnun: Fimm greiningarlíkön. Tímarit um viðskipti og efnahagsmál, 1 (1), 27-53.

Schultz, T. (1961). Investment in Human Capital. The American Economic Review. LI, (1), 1-17.

Taylor, F. W. (1997). Scientific management. Í Pugh, D. S. (ritstj.). Organization theory: Selected readings. London: Penguin Books.

Zárraga, C. og Bonache, J. (2003). Assessing the team environment for knowledge sharing: An empirical analysis. International Journal of Human Resource Management, 14 (7), 1227-1245. 